\title{
Impact of Tax Revenue on Government Expenditure in Ethiopia; OLS Method
}

\author{
Endashaw Sisay Sirah \\ MSc, Department of Economics, Mizan Tepi University, Mizan Aman, Ethiopia
}

\begin{abstract}
Factually, public expenditure has noted a nonstop uptrend over time in developing country. However, traditional thinking and philosophy did not favor the growth of public expenditure. Instead, it well thought-out market mechanism as a better guide in working of the economy and allocation of its resources. The empathy of the revenue-expenditure connection is vital to govern the correct course of action for fiscal discipline and fiscal policy. Basically the main objective of this study was to understand the impact of tax revenue on government expenditure in Ethiopia from the period of $1974 / 75$ to $2019 / 20$. In order to achieve the objective of this study a researcher used world development index and national bank of Ethiopia as a main data source. To found the impact of tax revenue on government expenditure the study employed Augmented Dickey Fuller, ordinary least square and pairwise granger causality test. For Ethiopia economy the result proved tax revenue and the previous expenditure has positive impact on government expenditure. The pairwise granger causality test also strength as there is causality which runs from tax revenue to government expenditure. The result of this study has been proved the first revenuespent (tax-spent) hypothesis. The study recommends that the government should increase tax base and practice proper administration of tax system and generate inordinate revenue. In somehow, it is used as a means to cover excess expenditure and to reduce budget deficit. Moreover, in Ethiopia from time to time there is population growth, increasing urbanization, provision of social overheads, maintenance of order and law, welfare activities, projects and provision of public goods and utility service. So, the previous started activates needs more expenditure to sustain them currently. This may lead to budget deficit but the government should balance its expenditure and revenue, plus to this the government should accomplished activities which started previously without dalliance, this help the government to minimize the current expenditure in somehow, and can save the country from sustainable budget deficit. Reduce spent for cosmetic activates which have no more return.
\end{abstract}

Keywords: Ethiopia, Impact, Tax, Expenditure, OLS

DOI: $10.7176 / \mathrm{JESD} / 10-13-06$

Publication date:July $31^{\text {st }} 2020$

\section{Introduction}

The theoretical contribution of Keynes has been influenced number of economists and a policy maker in order to direct the fiscal policy instruments like government expenditure and tax for the purpose of stabilizing economy without considerably changing prices (Aslan \& Tasdemir, 2009). From the major macroeconomics instruments (monetary and fiscal policy), fiscal policy has a great contribution in order to allocate government expenditure and tax revenue. In a given economy a sustainable budget deficit can be prevented if policy makers realize the connection between government spent and revenue which generated from the economy. Therefore for an interested body the impact of tax revenue on government expenditure has attracting a worth interest, because there is a debate in macroeconomics focusing on government expenditure and government revenue association.

Expenditure refers to the expenses which the government incurs for its own maintenance as also for the society and the economy as a whole. These days, some governments are incurring expenditure to help other countries and that would also from a part of public expenditure. With expanding state activities, it is becoming increasingly difficult to judge what portion of public expenditure can be ascribed to the maintenance of the government itself, and what portion to the benefit of the society and the economy. Historically, public expenditure has recorded a continuous uptrend over time in almost every country. However, traditional thinking and philosophy did not favor the growth of public expenditure. Instead, it considered market mechanism as a better guide in working of the economy and allocation of its resources. It was argued that each economic unit was the judge of its own economic interests and the government was certainly not able to decide on behalf of others. Furthermore, while a private economic unit was guided by its own economic interests, the public sector would have no such motivation (Abrams, 2017).

Lately, for developing countries there has been a bulging question for the sustainably incensement of government budget deficit where expenditure greater than total revenue. In Ethiopia budget deficit is a common phenomenon that has long period familiarity from 1974/75 to 2019/2020. The point here is that government expenditure used as a main engine so as to increase the power of economic growth to overcome the recorded problems which exist in a given economy, like to improve low living standard of a mass population, increasing the quality of services in each economic sector. In order to fulfill social over heads, i.e. education, infrastructure, health sector, defense, to give police service and the like a government needs to incur expenditure and those 
services takes a main responsible for the rising of government expenditure in a given economy, this also attract researchers to deal the contribution of government revenue on it. So, still those two variables are a main concern in public finance field (Ravinthirakumaran , 2011).

In Ethiopia in order to finance government spent there are many sources those are income from taxes and from other sources in which there is an element of compulsion. Secondly, the government gets income for services rendered to the public. These may be fees or prices of services rendered or profits of enterprises. Thirdly, there are certain sources of income which may not come under any of the above two types - they are not compulsory, nor are they voluntary payments. The main objective of this study was to investigate the impact of Tax revenue on government expenditure in Ethiopia from $1974 / 75$ to $2019 / 2020$. The study result may have its own policy implication for a concerned body. Moreover, in other developing and developed countries a number of studies have been conducted regarding to the relationship between government expenditure and government revenue. But there is no consistent result and particularly in Ethiopia this issue is not well touched and the country also has long period experience of budget deficit, so it needs further investigation.

\section{Theoretical and Empirical Literature Review}

So as to conduct a good decision and to improve the living standard of their societies, the government tries to plan budget. Regarding to budget there is also debate with the association of government revenue and government expenditure. So under this part different theories are referred to take clear understanding of those two issues. According to Peacock \& Wiseman (1979) when government has been increase its revenue leads to more expenditure also known as the first revenue-spent hypothesis. This implies the effect run from government revenue to government expenditure. The next hypothesis also explained that when government expenditure change cause for the change in government revenue, so here the impact goes from expenditure to revenue, which is called the second spend-revenue hypothesis. Another hypothesis also states that fiscal bringing together both government expenditure and government revenue without isolation. This statement proved that the impact run from government revenue to government expenditure and the reverse also true.

According to Keynes (1936) government has a major role to overcome economic problems like to reduce unemployment and increase aggregate demand, in order to address those issues Keynes has been advised the government to intervene our economy. Friedman (1978) hypothesis also explained that a government total revenue merely resolute it's spending, this imply that revenue affect government expenditure. When government increase taxes this imply high expenditure and budget deficit. This is also known as tax-spent hypothesis.

Al-Qudair (2005) examined government expenditure and revenue in the Kingdom of Saudi Arabia. This investigation used Co-integration technique and causality relationship with the integration of error correction model. The study proved that there is long run equilibrium between government revenue and expenditure. It also checking as there bi-directional causality between those variables in long run and short run. Champita (2016) addressed the causality which exists between government revenue and expenditure by using vector autoregressive model. The considered variables are gross domestic product, Treasury bill rates. The granger causality result showed that government expenditure granger cause government revenue. But for Namibia economy the result is opposite (Hinaunye \& Daisy, 2008).

Irandoust (2018) this study scrutinizes government expenditure and revenue to deal long run causality for Swedish economy from the period of 1722 to 2011 . This study used hidden co-integration and the amended version of the granger non-causality test. The study result indicates that there is long run and asymmetric relationship between government revenue and government expenditure. Ullah (2016) find the theoretical relationship between government revenue and expenditure for Malaysia economy by using four hypotheses. The study found that majority of government revenuer is from tax, but the government spent merely differs due to non-tax and indirect tax revenue.

\section{Methodology of the Study}

Table 1: Source of data

\begin{tabular}{|l|l|l|l|l|}
\hline Short form of Variables & Long form of Variables & Unit & Time & Data Source \\
\hline TR & Tax Revenue & \% of GDP & $1974 / 75-2019 / 2020$ & WDI and NBE \\
\hline GEXP & Government Expenditure & \% of GDP & $1974 / 75-2019 / 2020$ & WDI and NBE \\
\hline
\end{tabular}

According to the theoretical Fiscal Response Models (FRMs) the basic budget identity is total revenues, aid and borrowing must equal all expenditures;

Expenditures $=$ Borrowing + Aid + Revenues

Revenue may include tax revenue and non-tax revenue; domestic and foreign borrowings are included under borrowings; grants and loans consider under aid finally government capital and recurrent expenditure included under expenditure. So based on theoretical and empirical investigation like (Al-Qudair, 2005; Hinaunye \& Daisy, 2008; Ravinthirakumaran , 2011; Mehrara \& Rezaei , 2014) the researcher followed the following expression to see the impact of tax revenue on government expenditure in Ethiopia. General, functional, mathematical, 
Econometric and logarithmic form placed as follows respectively;

$\mathrm{Y}_{\mathrm{ij} 1975-2019}=\mathrm{f}\left(\mathrm{X}_{\mathrm{ij} 1975-2019)}\right.$.

Where $\mathrm{t}=$ time $(1975-2019), \mathrm{i}=$ raw vector and $\mathrm{j}=$ column vector.

EXPijt $=f\left(a i j, T_{i j t}\right)$.

The mathematical/economic representation;

$\mathrm{EXP}=\alpha \mathrm{ij}+\beta_{\mathrm{ij}} \mathrm{TR}_{\mathrm{ijt}}$

Econometric representation of the model;

Dependent variable $=$ systematic part + random part

Systematic part $=\mathrm{f}$ (explanatory variables) and the random part $=$ the error term

Therefore the dependent variable is the function of the explanatory variable and the error term;

$\mathrm{Yt}=\mathrm{f}$ (explanatory variable, error term), the dependent variable is known as explained, dependent, response or predicted variables.

$Y_{t}=f\left(X_{1 t}, X_{2 t}, X_{3 t}, \ldots \ldots, X_{4 t}\right)$

The population model with error term is;

$Y_{t}=a+\beta_{1} X_{1 t}+\beta_{2} X_{2 t}+\beta_{3} X_{3 t}+\ldots \ldots \ldots \beta_{n} X_{n t}+\mu_{t}$

$\mathrm{X}_{1 \mathrm{t}}, \mathrm{X}_{2 \mathrm{t}}, \mathrm{X}_{3 \mathrm{t}}, \ldots, \mathrm{X}_{\mathrm{nt}}$ Are the explanatory, independent, control, predictor or regressors variable. And $\mu_{\mathrm{t}}$ is represents all unobserved error factors influencing $Y_{i t}$ rather than $X_{i t}$, a is population intercept and $\beta s$ are population slope.

$\mathrm{EXP}=\alpha \mathrm{ij}+\beta_{\mathrm{ij}} \mathrm{TR}_{\mathrm{ijt}}+\mu_{\mathrm{ij}}$

Logarithmic transformation/log-log representation;

$\operatorname{LnBD}=\alpha \mathrm{ijTR} \mathrm{TR}_{\mathrm{ijt}} \mu^{\varepsilon \mathrm{ij}}$

$\operatorname{LnBD}=\alpha \mathrm{ij}+\beta_{\mathrm{ij}} \operatorname{LnTR}_{\mathrm{ijt}}+\varepsilon_{\mathrm{ij}}$

The estimated form of the model;

$\hat{y}=\hat{a}_{0}+\hat{b}_{1} \hat{x}_{1}+\hat{b}_{2} \hat{x}_{2}+\hat{b}_{3} \hat{x}_{3} \ldots \ldots+\hat{b}_{n} \hat{x}_{n}$

$\hat{a}_{0}$ Is the estimated mean value of $\hat{y}$ when $\hat{x}_{1}$ to $\hat{x}_{n}$ are zero, $\hat{b}_{1}$ to $\hat{b}_{n}$ shows the change in the estimated mean value of $\hat{y}$ at each independent variable, i.e. change $\hat{x}_{i} ; \Delta \hat{y}=\widehat{\beta}_{i} \Delta \hat{x}_{i}, i=1,2,3, \ldots \ldots, n$

\subsection{Hypothesis and some assumptions of OLS model}

F - test; Ho: $\mathrm{b} 1=\mathrm{b} 2=\mathrm{b} 3=\cdots \ldots .=\mathrm{bn}=0$, Ha: at least one is different from zero.

t - test; Ho: bi $=0$, Ha: bi $\neq 0$

For the above estimated model form (equation 9) the ceteris paribus interpretation manner is used. Here the study critically contemplate basic OLS assumptions, those are linearity in the parameter, normality of the error term, multicollinearity; the independent variables may not be independent, if we include more lag as independent variable. The covariance and correlations between different disturbances are all zero: $\operatorname{cov}(\mathrm{ut}, \mathrm{us})=0$ for all $\mathrm{t} \neq$ $\mathrm{s}$, this assumption states that the disturbances ut and we are independently distributed, which is called autocorrelation. This means that an error occurring at period t may be conceded over to the nextperiod $t+1$. Autocorrelation is most probable to happen in time series data. In cross-sectional we can change the arrangement of the data without changing the outcomes. One of the conventions of the linear regression model states that the residuals would have a constant variance independent of $\mathrm{t}$ : $\operatorname{Var}(\mathrm{ut})=\sigma 2$. Thus, taking constant variance means that the residuals is homoskedastic. If the assumption of homoskedasticity is dishonored thenVar(ut) $=\sigma \mathrm{t} 2$. For this research Stata-v-15 and E-views-v-10 econometric software has been applied.

\subsection{Stationary}

Most of the time, macroeconomic variables have unit root, i.e. if $\mu, \delta^{2}$ and $\gamma$ are not constant, this is leads us to produce spurious regression. Consequently, the investigator resolves this problem by converting non-stationary variables to stationary variables. Therefore the main objective of changing non stationary variable is to get constant $\mu, \delta^{2}$ and $\gamma$. If the time series data has constant $\mu, \delta^{2}$ and $\gamma$ then we call it stationary. To solve unit root problem this study was applying ADF test statistic. According to Sisay \& shah (2020), the three common properties of stationary time series are;
1. $E\left(Y_{t}\right)=E\left(Y_{t-s}\right)=\mu$
2. $E\left[\left(Y_{t}-\mu\right)\right]^{2}=E\left[\left(Y_{t-s}-\mu\right)\right]^{2}=\delta^{2}$
3. $\operatorname{Cov}\left(Y_{t}, Y_{t-s}\right)=\operatorname{Cov}\left(Y_{t-j}, Y_{t-j-s}\right): E\left[\left(Y_{t}-\mu\right)\left(Y_{t-s}-\mu\right)\right]=E\left[\left(Y_{t-j-s}-\mu\right)=\gamma\right.$

So we propose the Augmented Dickey-Fuller (ADF) test. For this three different regression equations are used to test for the presence of a unit root. 
$>$ Without drift and trend

$\Delta X_{t}=\gamma X_{t-1}+\sum_{i=1}^{p} \beta_{i} \Delta X+e_{t}$

$>$ With intercept

$\Delta X_{t}=\alpha_{0}+\gamma X_{t-1}+\sum_{i=1}^{p} \beta_{i} \Delta X+e_{t}$

$>$ With drift and trend

$\Delta X_{t}=\alpha_{0}+\gamma X_{t-1}+\theta T+\sum_{i=1}^{p} \beta_{i} \Delta X_{t-i}+e_{t}$

Where, $\Delta$ is difference operator, $\alpha_{0}$ is drift term, $\mathrm{P}$ is the lag order of the auto-regressive process, $\mathrm{T}=$ trend term/trend variable, $\mathrm{t}=$ time subscribe, $\beta_{i}=$ is a measure of lag length, $\gamma=\delta-1$, the coefficient of $X_{t-1}$ which measures the unit root, $\mathrm{e}=$ the error term $/$ is the white noise, $\theta=$ the coefficient on a time trend series, $\Delta X_{t}=$ $X_{t}-X_{t-1}$, are first difference of $X_{t}, X_{t-1}=$ Are lagged values of order one of $X_{t}, \Delta X_{t-i}=$ are changes in lagged values, $\Delta X_{t-1}=X_{t-1}-X_{t-2}, \Delta X_{t-2}=X_{t-2}-X_{t-3}$, the null and alternative hypotheses can be written as follows: $H_{o}: \gamma=0$,Non-stationary time series; so it has unit root problem. $H_{a}: \gamma<0$, Stationary time series; so it has not unit root problem. Based on the above general form of ADF unit toot test, here the researcher use the following format for $\left(\operatorname{LnTR} R_{t}\right)$ and $\left(\operatorname{LnEX} P_{t}\right.$ in order to test the null hypothesis (Sisay, 2019).

$>$ No drift and trend

$\Delta L n E X P_{t}=\gamma \operatorname{LnEX} P_{t-1}+\sum_{i=1}^{k} \beta_{i} \Delta L n E X P_{t-i}+\varepsilon_{t}$

$>$ With intercept but no trend

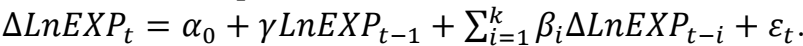

$>$ With intercept and trend

$\Delta \operatorname{LnEX} P_{t}=\alpha_{0}+\theta T+\gamma \operatorname{LnEX} P_{t-1}+\sum_{i=1}^{k} \beta_{i} \Delta \operatorname{LnEX} P_{t-i}+\varepsilon_{t}$

$>$ Without drift and trend

$\Delta \operatorname{LnTR}_{t}=\gamma \operatorname{LnTR} R_{t-1}+\sum_{i=1}^{k} \beta_{i} \Delta \operatorname{LnTR_{t-i}}+\varepsilon_{t}$

$>$ With intercept but not trend

$\Delta \operatorname{LnTR}_{t}=\alpha_{0}+\gamma L n T R_{t-1}+\sum_{i=1}^{k} \beta_{i} \Delta L n T R_{t-i}+\varepsilon_{t}$

$>$ With drift and trend

$\Delta L n T R_{t}=\alpha_{0}+\theta T+\gamma L n T R_{t-1}+\sum_{i=1}^{k} \beta_{i} \Delta L n T R_{t-i}+\varepsilon_{t}$

Decision rule for testing these hypotheses is: then ADF critical value is less than t-statistics null hypothesis will be reject, for this reason the tested variables is stationary (Sisay, 2020).

\subsection{Autoregressive Distributed Lag Model}

If the ADF test result is not appropriate to use OLS, then the researcher proposed co-integrating testing for X, Y variables through using the ARDL $\left(P, q_{1}, q_{2}, \ldots \ldots \ldots \ldots \ldots, q_{k}\right)$ model approach;

$$
\begin{aligned}
& \Delta \mathrm{X}_{\mathrm{t}}=\delta_{0 \mathrm{i}}+\sum_{\mathrm{i}=1}^{\mathrm{pi}} \mathrm{a}_{\mathrm{i}} \Delta \mathrm{X}_{\mathrm{t}-1}+\sum_{\mathrm{i}=1}^{\mathrm{qi}} \mathrm{a}_{2} \Delta \mathrm{Y}_{\mathrm{t}-\mathrm{i}}+\delta_{1} \mathrm{X}_{\mathrm{t}-1}+\delta_{2} \mathrm{Y}_{\mathrm{t}-1}+\mathrm{V}_{1 \mathrm{t}} \cdots \\
& \Delta \mathrm{Y}_{\mathrm{t}}=\delta_{0 \mathrm{i}}+\sum_{\mathrm{i}=1}^{\mathrm{p}} \mathrm{a}_{\mathrm{i}} \Delta \mathrm{Y}_{\mathrm{t}-1}+\sum_{\mathrm{i}=1}^{\mathrm{qi}} \mathrm{a}_{2} \Delta \mathrm{X}_{\mathrm{t}-\mathrm{i}}+\delta_{1} \mathrm{Y}_{\mathrm{t}-1}+\delta_{2} \mathrm{X}_{\mathrm{t}-1}+\mathrm{V}_{1 \mathrm{t}} \cdots
\end{aligned}
$$

Equation (18a) and (18b) are the general form; $\mathrm{P}_{\mathrm{i}}$ and $\mathrm{q}_{\mathrm{i}}$ are the ARDL model maximum lag order for dependent and independent variables, $\mathrm{V}_{1 \mathrm{t}}$ is the vector error term, $\delta_{0 i}$ is vector intercept term. Variable $\delta_{1} X_{t-1}$, $\delta_{1} Y_{t-1}, \delta_{2} Y_{t-1}$ and $\delta_{2} X_{t-1}$ correspond to the long run relationship. While $\left(a_{i}\right.$ to $\left.a_{2}\right)$ represent the short run dynamics of the model. The hypothesis that the coefficients of the lag level variables are zero is to be tested (Pesaran et al., 2001). The null of non-existence of the long-run relationship is defined by; $H_{0}: \delta_{1}=\delta_{2}=0$ (Null, i.e. the long run relationship does not exist), $H_{1}: \delta_{1} \neq \delta_{2} \neq 0$ (Alternative, i.e. the long run relationship exists) (Sisay, 2020).

Then and there the ARDL model for LnTR and LnEXP appears as follows;

$\mathrm{D}(\operatorname{Ln}(\mathrm{EXPt}))=\beta 1+\alpha 11 \operatorname{Ln}(\mathrm{EXPt}-1)+\alpha 21 \operatorname{Ln}(\mathrm{TRt}-1)+\Sigma p i 1 \theta 1 \mathrm{i} \mathrm{D}(\operatorname{Ln}(\mathrm{EXPt}-1))+$

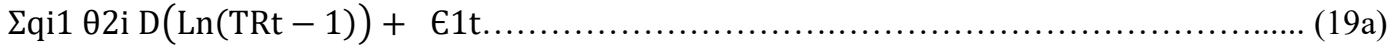

Causality of Variables;

$\mathrm{D}\left(\operatorname{Ln}\left(\mathrm{EXP}_{\mathrm{t}}\right)\right)=\theta_{0}+\sum_{\mathrm{i}=1}^{\mathrm{p}} \theta_{1 \mathrm{i}} \mathrm{D}\left(\operatorname{Ln}\left(\mathrm{EXP}_{\mathrm{t}-\mathrm{i}}\right)\right)+\sum_{\mathrm{i}=1}^{\mathrm{q}} \theta_{2 \mathrm{i}} \mathrm{D}\left(\operatorname{Ln}\left(\mathrm{TR}_{\mathrm{t}-\mathrm{i}}\right)\right)+\varepsilon_{\mathrm{t}}$

$\mathrm{D}\left(\operatorname{Ln}\left(\mathrm{TR}_{\mathrm{t}}\right)\right)=\theta_{0}+\sum_{\mathrm{i}=1}^{\mathrm{p}} \theta_{1 \mathrm{i}} \mathrm{D}\left(\operatorname{Ln}\left(\mathrm{TR}_{\mathrm{t}-\mathrm{i}}\right)\right)+\sum_{\mathrm{i}=1}^{\mathrm{q}} \theta_{2 \mathrm{i}} \mathrm{D}\left(\operatorname{Ln}\left(\mathrm{EXP}_{\mathrm{t}-\mathrm{i}}\right)\right)+\varepsilon_{\mathrm{t}}$

\section{Result of the study}

Table 2: Augmented Dickey-Fuller test

\begin{tabular}{|l|l|l|l|l|}
\hline Variables & t-statistics & ADF-P-value & Lag (AIC) & Decision \\
\hline LNEXP & 3.071487 & 0.0363 & 1 & No Unit Root at I $(0)$ \\
\hline LNTR & 2.948642 & 0.0479 & 1 & No Unit Root at I $(0)$ \\
\hline
\end{tabular}

Source: E-views v-10

Note:- AIC is Akaike Information Criteria, 5\% Significance Level

The unit root test shows both variables are stationary at level, so there is no unit root problem. 


\subsection{Diagnostic Test}

Table 3: Diagnostic Test of Model and Residual

\begin{tabular}{|c|c|c|c|}
\hline & i & Normality Test & \\
\hline Skewness & Kurtosis & Jarque - Bera & Probability \\
\hline 0.643841 & 2.716912 & 3.186815 & 0.203232 \\
\hline & ii. & Autocorrelation test & \\
\hline & Breusch-Gor & frey Serial Correlation LM Test: & \\
\hline F-statistic & 0.188359 & Prob. F(2,39) & $=0.8291$ \\
\hline Obs $* \mathrm{R}-$ squared & 0.420948 & Prob. Chi-Square(2) & $=0.8102$ \\
\hline & iii. & Heteroskedasticity Test & \\
\hline & Heteroskedastici & y Test: Breusch - Pagan - Goc & dfrey \\
\hline F-statistic & 0.067836 & Prob. F(2,41) & $=0.9345$ \\
\hline$O b s * \mathrm{R}$-squared & 0.145119 & Prob. Chi-Square(2) & $=0.9300$ \\
\hline Scaled explained SS & 0.108169 & Prob. Chi-Square(2) & $=0.9474$ \\
\hline & & Ramsey test & \\
\hline Statistics Name & Value & Degree of freedom & Probability \\
\hline t-statistic & 0.650959 & 40 & 0.5188 \\
\hline F-statistic & 0.423748 & $(1,40)$ & 0.5188 \\
\hline Likelihood ratio & 0.463671 & 1 & 0.4959 \\
\hline & v. & Multicollinearity Tests & \\
\hline Variable & Coefficient Variance & Uncentered VIF & Centered VIF \\
\hline $\operatorname{LEXP}(-1)$ & 0.007219 & 296.2078 & 1.719118 \\
\hline LTR & 0.010775 & 248.6833 & 1.719118 \\
\hline $\mathrm{C}$ & 0.039932 & 193.6111 & NA \\
\hline
\end{tabular}

The model is free from multicollinearity, Hetroskedasticity, Ramsey RESET test and autocorrelation problem. Moreover there is normality, linearity of parameters and the model is stable.
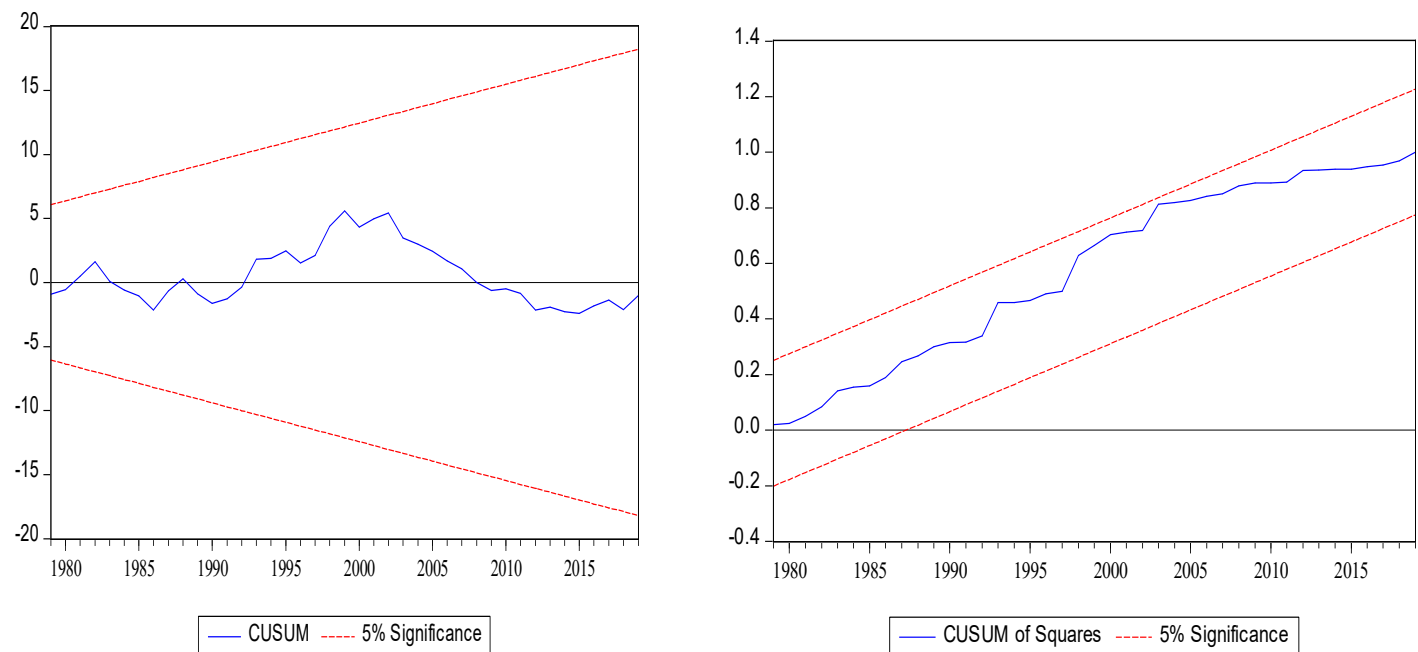

Figure 2: Model stability test

Estimation result;

$\mathrm{y}=\mathrm{a}+\widehat{\beta}_{1} \operatorname{LnTR}+\widehat{\beta}_{2} \operatorname{LnEXP}(-1)$

$\operatorname{LnEXP}=0.35+0.37 \operatorname{LnTR}+0.60 \operatorname{LnEXP}(-1)$

$$
\text { [0.0008] [0.0000] }
$$

\section{Significance of variables (t-test);}

tcalculated of $\operatorname{LnTR}=\frac{\operatorname{coe} \widehat{\beta}_{1}}{\operatorname{se}\left(\widehat{\beta}_{1}\right)}$

tcalculated of $\operatorname{LnEXP}(-1)=\frac{\operatorname{coe} \widehat{\beta}_{2}}{\operatorname{se}\left(\widehat{\beta}_{2}\right)}$

$$
=\frac{0.374149}{0.103801}=3.604479
$$




$$
=\frac{0.604473}{0.084964}=7.114475
$$

From the above the calculated t values show that each variable are significant, we have evidence as those listed variables are different from zero.

\section{$>$ Significance of variables (f-test);}

(1) $\operatorname{LnTR}=0$, (2) LnEXPlag $=0, \mathrm{~F}(2,41)=83.19$, Prob $>\mathrm{F}=0.0000$

The f-test proved that both variables are highly significant. So the model is good in predicting government expenditure.

$>$ Testing linear combination of variables (t-test);

Ho: coefficient of $\operatorname{LnTR}=$ coefficient of $\operatorname{LnEXP}(-1)$ and Ha: coefficient of $\operatorname{LnTR}$ and $\operatorname{LnEXP}(-1)$ are not equal. Let $\emptyset=$ coefficient of LnTR - coefficeint of $\operatorname{LnEXP}(-1)$, Then Ho: $\varnothing=0$ Ha: $\varnothing \neq 0$

Standard deviation $(\widehat{\varnothing})=\sqrt{\text { varaince of } \varnothing}$

$\operatorname{var}(\widehat{\varnothing})=\operatorname{var}\left(\widehat{\beta}_{1}-\widehat{\beta}_{2}\right)=\operatorname{var}\left(\widehat{\beta}_{1}\right)+\operatorname{var}\left(\widehat{\beta}_{2}\right)-2 \operatorname{cov}\left(\widehat{\beta}_{1}, \widehat{\beta}_{2}\right)$

Variance of LnTR coefficient $=0.01077466$, Variance of $\operatorname{LnEXP}(-1)$ coefficient $=0.00721884$ and the covariance of coefficient LnTR and $\operatorname{LnEXP}(-1)=-0.00570404$

$$
\begin{aligned}
& \operatorname{var}(\widehat{\varnothing})=0.00658542 \text { And se }(\widehat{\varnothing})=0.081 \\
& \text { tcalculated }=\frac{\widehat{\beta}_{2}-\widehat{\beta}_{1}}{\operatorname{se}(\widehat{\varnothing})}
\end{aligned}
$$

tcalculated $=0.23 / 0.081=2.83$, it is statistical significant at $1 \%, 5 \%$ and $10 \%$ with a critical value of 2.423 , 1.684 and 1.303 respectively at $42 d f$. We have clear evidence to reject null hypothesis, because $\hat{\beta}_{1}$ is statistically different from $\hat{\beta}_{2}$, this also proved table 3 as there is no multi-collinearity problem.

$>$ R-Squared

$\mathrm{R}-$ Squared $=$ Explained sum of square $/$ Total Sum of Square $=$ ESS $/$ TSS $=$ TSS - RSS $/$ TSS $=1-$ RSS/TSS

Then according to question number (23) the result of $\mathrm{R}$ - Squared is equal to $0.8023 / \mathrm{R}=0.8957$

\section{$>$ Adjusted R-Squared}

$\overline{\mathrm{R}}^{2}=1-\left[\frac{\sum \mathrm{e}_{\mathrm{i}}^{2} / \mathrm{N}-\mathrm{K}}{\sum \mathrm{y}_{\mathrm{i}}^{2}(\mathrm{~N}-1)}\right]=1-\frac{\widehat{\sigma}^{2}}{\mathrm{~S}_{\mathrm{y}}^{2}}$

When we substitute each value, we have an opportunity to get the adjusted R -squared (0.7926)

Table 7: Pairwise Granger Cause Tests

\begin{tabular}{|l|l|l|l|}
\hline Null Hypothesis & Observation & F-Statistics & Probability \\
\hline LnTR does not Granger Cause LEXP & 44 & 4.02571 & 0.0514 \\
LnEXP does not Granger Cause LTR & & 0.54273 & 0.4655 \\
\hline
\end{tabular}

Source: E-views-v-10

The result proved that tax revenue and previous government expenditure has positive impact on government expenditure in Ethiopia. Those two variables also explained the dependent variable by $80 \%$. It is support revenuespent hypothesis. This also sustenance with pairwise granger causality tests, i.e. tax revenue is granger case government expenditure. But government expenditure is does not granger cause tax revenue so we conclude that there is only unidirectional causality which run from tax revenue to government expenditure. This causality relationship is consistent from (Hinaunye \& Daisy, 2008); Mehrara \& Rezaei, 2014). But according to (Ravinthirakumaran , 2011) and (Al-Qudair, 2005) government expenditure and government revenue is bidirectional causality. Therefore when tax revenue and previous government expenditure increased by $1 \%$, the current expenditure increased by $37 \%$ and $60 \%$ respectively. In Ethiopia from time to time there is population growth, increasing urbanization, provision of social overheads, maintenance of order and law, welfare activities, projects and provision of public goods and utility service. So, the previous started activates needs more expenditure to sustain them currently. This may lead to budget deficit but the government should balance its expenditure and revenue, plus to this the government should accomplished activities which started previously without dalliance, this help the government to minimize the current expenditure in somehow, and can save the country from sustainable budget deficit.

\section{Conclusion and Recommendation}

\subsection{Conclusion}

This analysis applied OLS/ARDL estimation method to examine the impact of tax revenue and government 
expenditure in Ethiopia. To check the appropriateness of OLS model and the initiate result of this study, it is free frommulticollinearity, Heteroskedasticity, Ramsey RESET test and autocorrelation problem. Moreover the diagnostic test proved that as there is normality and linearity of parameters and the model is stable.

\subsection{Recommendations}

Therefore when tax revenue and previous government expenditure increased by $1 \%$, the current expenditure increased by $37 \%$ and $60 \%$ respectively. In Ethiopia from time to time there is population growth, increasing urbanization, provision of social overheads, maintenance of order and law, welfare activities, projects and provision of public goods and utility service. So, the previous started activates needs more expenditure to sustain them currently. This may lead to budget deficit but the government should balance its expenditure and revenue, plus to this the government should accomplished activities which started previously without dalliance. These help the government to minimize the current expenditure in somehow, and can save the country from sustainable budget deficit. Moreover, expenditure should be productive and reduce spent for cosmetic activates which have no more return.

\section{Reference}

Champita, M. (2016). Causality between Government Revenue and Expenditure: Empirical E vidence from Zambia. Zambia Social Science Journa, 6(1), 47-64.

Irandoust, M. (2018). Government spending and revenues in Sweden1722-2011: evidence from hidden cointegration. Empirica, 543-557.

Ullah, N. (2016). The Relationship Of Government Revenue And Governmentexpenditure: A Case Study Of Malaysia. International Center For Education In Islamic Finance, 1-20.

Abrams, T. M. (2017). Aid, taxes and government spending:A heterogeneous, cointegrated panel analysis, CREDIT Research Paper, No. 17/02, The University of Nottingham, Centre for Research in Economic Development and International Trade (CREDIT), Nottingham.

Al-Qudair, K. H. (2005). The Relationship betweenGovernment Expenditure and Revenues in the Kingdom of Saudi Arabia:Testing for Cointegration and Causality. JKAU: Econ. \& Adm, 19(1), 31-43.

Aslan, M., \& Tasdemir, M. (2009). Is Fiscal Synchronization Hypothesis Relevant for Turkey? Evidence from Cointegration and Causality Tests with Endogenous Structural Breaks. Journal of Money, Investment and Banking.

Friedman, M. (1978). The Limitations of Tax Limitation. Policy Review, 5(78), 7-14.

Hinaunye, E. J., \& Daisy, M. (2008). The Causal Relationship Between Government Revenue And Expenditure In Namibia. Munich Personal RePEc Archive, 1-18.

Keynes, J. M. (1936). The Genera l Theor y of Employment, Inter est a nd Money. New York: Harcourt Brace Jovanovich, I nc.

Mehrara, M., \& Rezaei , A. a. (2014). The Relationship between Government Revenue and Government Expenditure in Iran. International Journal of Academic Research in Business and Social Sciences, 4(3), 171182.

Peacock , M. S., \& Wiseman, J. (1979). Approaches to theAnalysis of Government Expenditures. PublicFina nce Quarterly, 7, 3-23.

Pesaran, M. H., Shin, Y., \& Smith, R.J. (2001). Bounds testing approaches to the analysis of level relationships. Journal of Applied Econometrics, 16 (3), pp. 289-326

Ravinthirakumaran , K. (2011). The Relationship between Government Revenue and Expenditure in Sri Lanka. Faculty of Commerce and Management Studies, 1-16.

Sisay, E. (2019). Causality of Unemployment and Macroeconomics in Ethiopia. Global journal of Economics and Business Administration, 4(24).

Sisay, E. (2020). Macroeconomic Determinants of Unemployment in Ethiopia. Global Scientific Journal, 8(02), 4718-4729.

Sisay, E., \& shah, S. A. (2020, February). The Correlation Between Real Growth Domestic Product And Unemployment In Ethiopia. International Journal of Current Research, 12(02), pp.10213-10218. 